\title{
Characterization and Exploitation of El-Gedida High-Mn Iron Ore, El-Bahariya Oasis, Western Desert, Egypt
}

\author{
Galal H. El-Habaak ${ }^{1}$, Mohamed S. Askalany ${ }^{2}$, Mohamed G. Farghaly ${ }^{3}$, \\ Mahmoud S. Abdel-Hakeem ${ }^{2, *}$ \\ ${ }^{1}$ Department of Geology, Faculty of Science, Assiut University, Assiut, Egypt \\ ${ }^{2}$ Department of Geology, Faculty of Science, South Valley University, Qena, Egypt \\ ${ }^{3}$ Department of Mining and Petroleum Engineering, Faculty of Engineering, El-Azhar University, Qena, Egypt
}

Email address:

mahmoud.sabry@sci.svu.edu.eg (M. S. Abdel-Hakeem)

${ }^{*}$ Corresponding author

\section{To cite this article:}

Galal H. El-Habaak, Mohamed S. Askalany, Mohamed G. Farghaly, Mahmoud S. Abdel-Hakeem. Characterization and Exploitation of ElGedida High-Mn Iron Ore, El-Bahariya Oasis, Western Desert, Egypt. American Journal of Energy Engineering.

Vol. 4, No. 4, 2016, pp. 34-39. doi: 10.11648/j.ajee.20160404.11

Received: November 25, 2016; Accepted: December 27, 2016; Published: January 17, 2017

\begin{abstract}
Two strategies have been chosen for the exploitation of El-Gedida high-Mn iron ore containing 46.37 wt. $\%$ Fe and $7.53 \mathrm{wt} . \% \mathrm{Mn}$. The first one included magnetic roasting and subsequent low intensity magnetic separation. The second strategy involved a blend process of the El-Gedida high-Mn iron ore with the Um Bogma manganese ore. The magnetic separation failed to reduce the Mn content up to $4 \mathrm{wt} . \%$ and produced iron concentrate containing $52.15 \mathrm{wt} . \% \mathrm{Fe}$ with a recovery of $94.47 \%$ and 6.45 wt. $\%$ Mn with a recovery of $71.95 \%$. At this point, the magnetic separation is considered to be unsuitable process for upgrading the high-Mn iron ore. Moreover, this physical separation supported the microscopic prediction regarding the difficult liberation of iron minerals from manganese phase during the comminution process. On the other hand, blending the high-Mn iron ore with the Um Bogma manganese ore at weight ratio of 1/6 (El-Gedida sample/Um Bogma sample) produced a suitable mixture for making the ferromanganese alloys.
\end{abstract}

Keywords: El-Gedida Mine, High-Mn Iron Ore, Um Bogma Area, Manganese Ore, Magnetic Separation, Blend Process

\section{Introduction}

Egypt is endowed with huge amounts of mineral resources among which the ironstone deposits located at the El-Gedida mine, El-Bahariya Oasis, Western Desert, Egypt. This mining area contains 126.7 million metric tons of iron ores that are considered the only commercial oolitic ironstone in the northern Africa and southern Europe [1]. These iron ore deposits are the main iron raw material supplied for the Egyptian iron and steel company, Helwan, Cairo; from 1973 until now. One million metric ton of the El-Gedida iron ore suffers from the high content of $\mathrm{BaO}$ reported up to 36.87 wt.\% [2]. The high percentage of $\mathrm{BaO}$ present in the iron ore is considered one of the problems which face the production of pig iron in the blast furnace at Helwan. Increasing $\mathrm{BaO}$ present makes the reduction process more energy consumption due to the high thermal stability of barite $\left(1580^{\circ} \mathrm{C}\right)$; moreover, the undesirable barium content decreases the quality of the produced pig iron [3]. The baritic iron ore of El-Gedida mine was magnetically processed by Farghaly [2]. He used the dry high intensity magnetic separation together with reduction roasting and obtained final product assaying 56.78 wt. $\% \mathrm{Fe}$ and $1.61 \mathrm{wt} . \% \mathrm{BaO}$ at recovery of $82.76 \%$ from a head sample containing 23.5 wt. $\% \mathrm{Fe}$ and 34 wt. $\% \mathrm{BaO}$.

Besides the high content of $\mathrm{BaO}$, the El-Gedida iron ore is faced with another challenge represented by the high content of Mn reaching up to $7.66 \mathrm{wt} . \%$ [4]. This high-Mn iron ore is reported at reserves 5.3 million metric tons [5]. The concentration of $\mathrm{Mn}$ in the iron raw materials must be at allowable content $4 \%$ [6]. The concentrations above $4 \%$ definitely result in forming strong oxides of manganese that influence the reduction process of iron oxides in the blast furnace [7-9]. Little studies have dealt with the high-Mn iron 
ore of El-Gedida mine. Baioumy et al. [5] studied the high$\mathrm{Mn}$ iron ore located at Ghorabi mine (northeast the Bahariya depression) in terms of mineralogy, geochemistry and origin. The authors suggested a supergene origin for this ore type. The present paper sheds the light on the origin of El-Gedida high-Mn iron ore and suggeststwo strategies, separation and blend processes,for exploiting this problematic iron ore. The separation process endeavors to obtain iron concentrate with Mn content $\leq 4 \mathrm{wt} . \%$, while the main aim of blend process is to obtain suitable mixture for the manufacturing of ferromanganese alloys. The proved reserves of Um Bogma manganese ore, blend material, is 170 million metric tons with high content of manganese reaching up to $89.51 \mathrm{wt} . \%$ $\mathrm{MnO}_{2}$ [10-12]. Hence, the reserves and Mn content of Um Bogma manganese ore are indicators on the possibility and economic potential of the blend process.

\section{Materials and Methods}

The used samples in the present study are represented by a high-Mn iron ore obtained from the western side of ElGedida iron mine (Figure1) and a high grade manganese ore obtained from the Um Bogma area, Sinai. The high-Mn iron ore was petrographically studied using the reflected light optical microscope.

The bulk mineralogy of iron and manganese ores was determined using a Philips X-ray diffractometer (X'Pert PRO-PAN) hosted at Assiut University, Egypt. The XRD data was interpreted using X'Pert High Score Software. The chemical composition of these ores was investigated using XRF hosted at the Egyptian Geological Survey. For major oxides, fused beads were prepared by mixing the powdered samples with the flux $(57 \%$ Li-tetraborate and $47 \% \mathrm{Li}$ metaborate) at sample/flux ratio of $0.33 / 2.5 \mathrm{~g}$. The process of fusion was performed in platinum-gold crucibles. Loss on ignition (L.O.I) was determined by heating the powdered samples up to $1000^{\circ} \mathrm{C}$ for 6 hours.

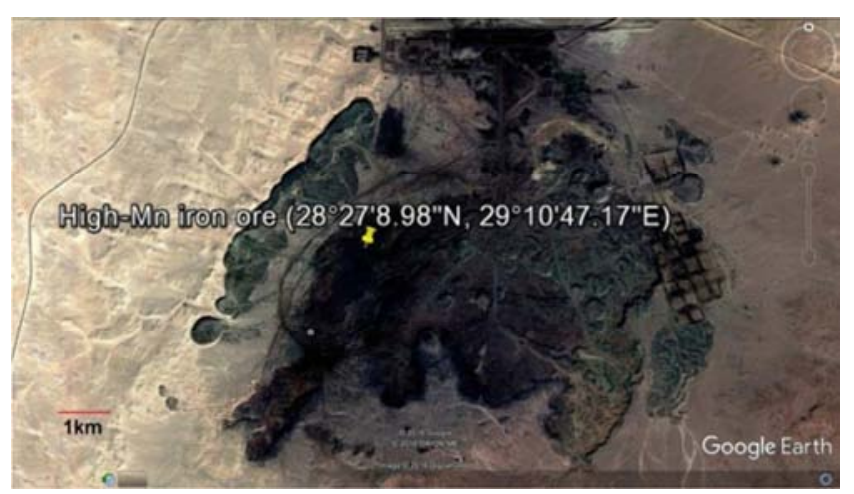

Figure 1. Image satellite showing the location of high-Mn iron ore section at the western wadi of El-Gedida iron mine.

Regarding the separation process, a representative sample of the high-Mn iron ore was subjected to crushing and grinding processes using jaw crusher and hammer mill. The size reduction process was conducted in a closed circuit along with mesh \#100 $(150 \mu \mathrm{m})$ until the whole sample became- $150 \mu \mathrm{m}$. Both comminution and sieving processes were followed by magnetic roasting for converting iron oxides and hydroxides to more magnetic phases (magnetite) which enables the magnetic separation at low intensity leaving behind the other non magnetic phases, manganese minerals in the present case [13]. The roasting procedure started with mixing $15 \mathrm{~g}$ of the ground ore with $9 \mathrm{~g}$ of coke (reducing agent). The mixture was then heated up to $650^{\circ} \mathrm{C}$ for $80 \mathrm{~min}$. The roasted product was mineralogically investigated to determine the efficiency of roasting process. Afterwards, the separation process was performed for the roasted sample $(15 \mathrm{~g})$ using wet low intensity magnetic separator adjusted at $120 \mathrm{Am}$ and $150 \mathrm{~V}$. Both magnetic and non magnetic fractions were chemically assayed for iron and manganese contents.

Besides the magnetic separation, the blend process is considered the second strategy for converting the El-Gedida high-Mn iron ore from problematic ore to a commercial material can contribute to the manufacture of ferromanganese alloys. For performing this process, $200 \mathrm{~g}$ representative sample of the Um Bogma manganese ore was ground to the same size as El-Gedida high-Mn iron ore $(-150 \mu \mathrm{m})$. The mixing process was carried out at five weight ratios of ElGedida high-Mn iron ore/ Um Bogma manganese ore (1/2, $1 / 3,1 / 4,1 / 5$ and 1/6). The efficiency of mixing process was monitored by performing chemical analyses for each weight ratio.

\section{Results and Discussion}

\subsection{Microscopic Characterization}

Hematite, the chief iron mineral in the studied samples, is found as agglomerated granules, pellets, or idiomorphic crystals ranging from 0.3 to $0.65 \mathrm{~mm}$ in size. The interstitial spaces between hematite grains are frequently infilled with goethite or pyrochroite (Figure 2.a). Occasionally, alteration rims of cryptomelane are observed around hematite grains (Figure 2.b). Also, cryptomelane has been reported as connected network inside some hematite grains (Figure 2.c) and botryoidal masses inside a groundmass of hematite (Figure 2.d).

Besides its role in identifying the mineral phases, the optical microscope can predict the liberation degree of mineral deposit by studying the nature of grain boundaries between the different mineral phases of such deposit. This prediction of liberation degree can contribute to save the energy consumed during the mineral processing operations [14]. The high-Mn iron ore shows intergranular and net-like textural relationships between iron and manganese minerals. These textural relationships refer to the probability of difficult liberation during the comminution process [15-16].

\subsection{Mineralogical Characterization}

Interpretation of XRD patterns of the high-Mn iron ore (Figure 3.a) indicates the iron minerals are represented hematite and goethite, while the Mn phases are represented 
by cryptomelane, pyrochroite, bixbyite and rhodochrosite. Also, traces of quartz and glauconite were detected. On the other side, the Um Bogma manganese ore is composed of psilomelane and pyrolusite with small quantities of hematite, quartz, halloysite and barite (Figure 3.b).

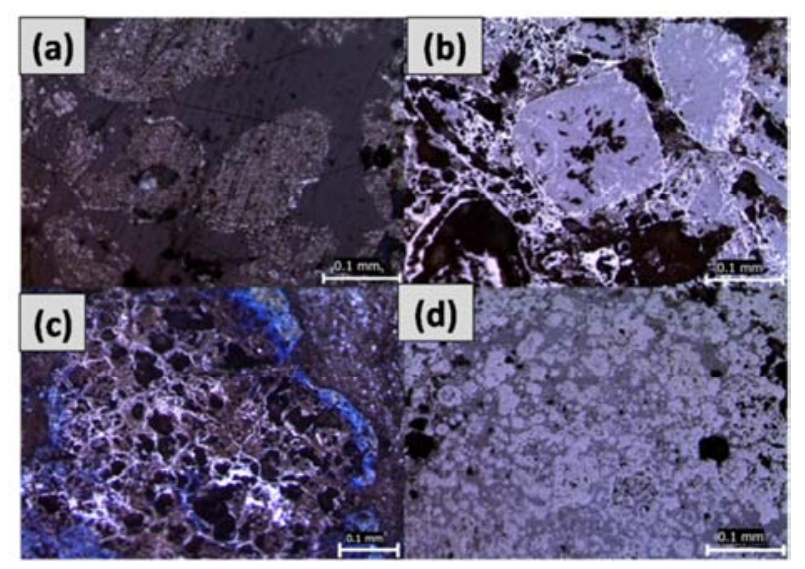

Figure 2. Photomicrographs showing an intergranular locking between hematite pellets (light grey) and pyrochroite (medium grey) (a), fibrous rims of cryptomelane (white) around the perpheries of hematite grains (bluish grey) (b), net-like locking between cryptomelane (white) and hematite (brownish grey) (c), and botryoidal masses of cryptomelane (white) cemented by hematite-rich groundmass (brownish grey) (d).
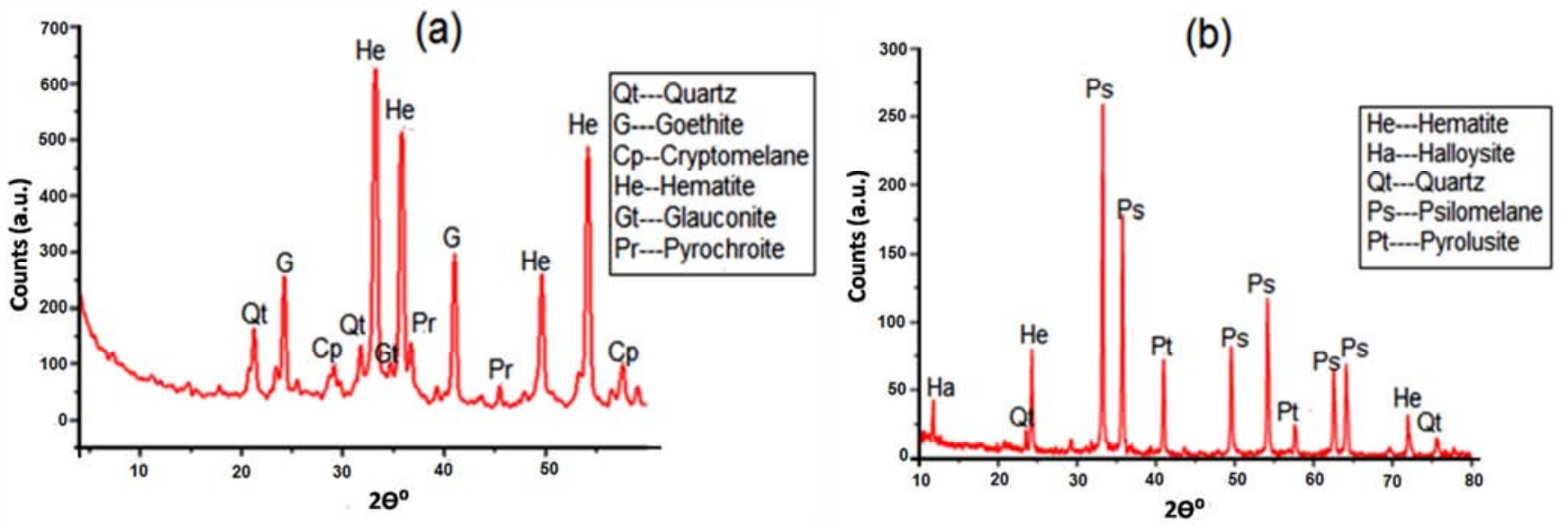

Figure 3. XRD patterns of El-Gedida high-Mn iron ore (a) and Um Bogma manganese ore (b).

\subsection{Chemical Characterization}

As listed in Table 1, the chemical analysis of El-Gedida high-Mn iron ore reveals that the total contents of iron and manganese are 46.37 wt.\% Fe and 7.53 wt.\% Mn, respectively. According to Pihura et al. [6], the maximum content of manganese in iron ores exploited for the steelmaking must not be more than $4 \mathrm{wt} . \% \mathrm{Mn}$. The high content of manganese in the studied iron ore will cause increasing the consumed quantity of coke during the reduction process and a detrimental effect on the productivity and life time of the blast furnace [17]. So, the studied high$\mathrm{Mn}$ iron ore is not suitable for the direct metallurgical exploitation. On the other side, the Um Bogma manganese sample contains $65.0 \mathrm{wt} \% \mathrm{Mn}$ and $2.11 \mathrm{wt} \%$ Fe. The slag components $\left(\mathrm{SiO}_{2}+\mathrm{Al}_{2} \mathrm{O}_{3}\right)$ are reported at $1.11 \mathrm{wt} \%$ for the high-Mn iron ore and 1.33 wt. $\%$ for the Um Bogma manganese ore. The contents of $\mathrm{P}_{2} \mathrm{O}_{5}$ are $0.11 \mathrm{wt} . \%$ and 0.07 wt.\% for the El-Gedida iron ore and Um Bogma sample, respectively. Also, the contents of $\mathrm{SO}_{3}$ are low and reported as $0.90 \mathrm{wt} . \%$ and $0.06 \mathrm{wt} . \%$ for the El-Gedida iron ore and Um Bogma manganese ore, respectively.

Table 1. Chemical analyses of El-Gedida and Um Bogma head samples.

\begin{tabular}{lll}
\hline Oxides (100\%) & El-Gedida sample & Um Bogma sample \\
\hline $\mathrm{SiO}_{2}$ & 1.03 & 0.88 \\
$\mathrm{TiO}_{2}$ & 0.06 & 0.54 \\
$\mathrm{Al}_{2} \mathrm{O}_{3}$ & 0.08 & 0.45 \\
$\mathrm{MnO}$ & 9.72 & 88.93 \\
$\mathrm{Mn}_{\text {total }}$ & 7.53 & 68.87 \\
$\mathrm{Fe}_{2} \mathrm{O}_{3}$ & 66.29 & 3.01 \\
$\mathrm{Fe}_{\text {total }}$ & 46.37 & 2.11 \\
$\mathrm{MgO}$ & 0.26 & 0.29 \\
$\mathrm{CaO}$ & 4.65 & 0.43 \\
$\mathrm{Na}_{2} \mathrm{O}$ & 1.85 & 0.49 \\
$\mathrm{~K}_{2} \mathrm{O}$ & 0.18 & 0.86 \\
$\mathrm{P}_{2} \mathrm{O}_{5}$ & 0.11 & 0.07 \\
$\mathrm{SO}_{3}$ & 0.90 & 0.06 \\
$\mathrm{Cl}$ & 2.48 & 0.08 \\
L.O.I. & 12.00 & 3.85 \\
\hline
\end{tabular}




\subsection{Magnetic Separation}

The mineralogical analysis of the roasted iron ore sample refers to the complete transformation of hematite to magnetite, with further converting the produced magnetite to wustite (Figure 4).

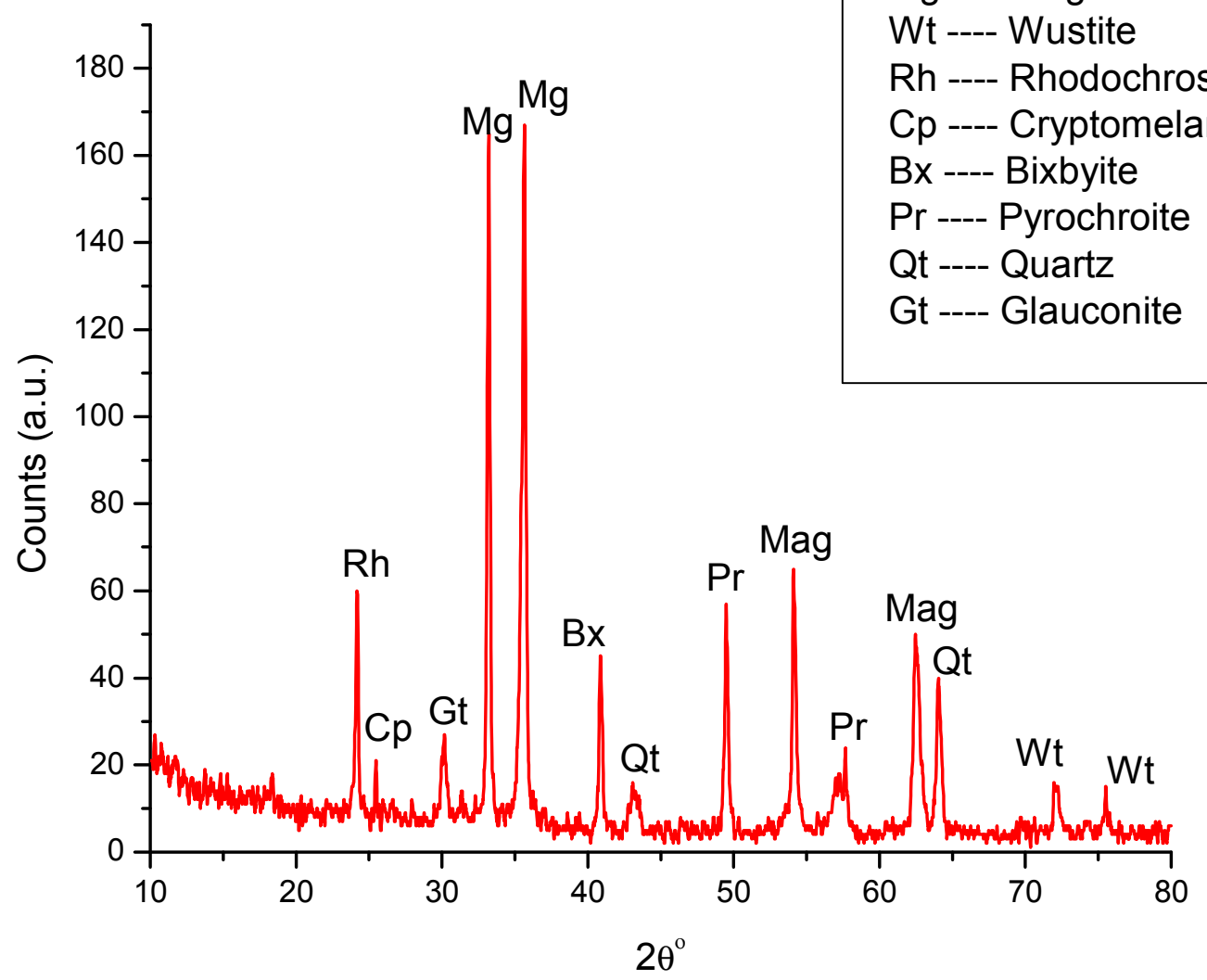

Figure 4. XRD pattern of the roasted sample of El-Gedida high-Mn iron ore.

After roasting, the separation process of El-Gedida high$\mathrm{Mn}$ iron ore produced magnetic and nonmagnetic fractions. The magnetic fraction accounts for $84 \mathrm{wt} . \%$ of the roasted sample and contains 52.15 wt.\% Fe with a recovery of $94.47 \%$ and $6.45 \mathrm{wt} . \% \mathrm{Mn}$ with a recovery of $71.95 \%$, as shown in Table 2. The non-magnetic fraction comprises 16 wt. $\%$ of the roasted sample and contains 15.4 wt. $\%$ Feand 12.89 wt. $\% \mathrm{Mn}$. The iron content present in the non-magnetic fraction can be attributed to the further conversion of magnetite to wustite that is well known with its diamagnetic property [2]. However, the process of magnetic separation resulted in a magnetic fraction that contains manganese above the tolerant concentration. Thus, the separation process is unsuitable method for converting the high-Mn iron ore from invaluable material to commercial raw material.

Table 2. Chemical assay of the magnetic fraction obtained from the high-Mn iron ore.

\begin{tabular}{|c|c|c|c|c|c|c|c|c|c|c|c|c|}
\hline \multirow{3}{*}{$\begin{array}{l}\text { Sample } \\
\text { Magnetic } \\
\text { fraction }\end{array}$} & \multicolumn{12}{|c|}{ Oxides $(100 \%)$} \\
\hline & $\mathrm{SiO}_{2}$ & $\mathrm{TiO}_{2}$ & $\mathrm{Al}_{2} \mathrm{O}_{3}$ & $\mathrm{Mn}_{\text {total }}$ & $\mathrm{Fe}_{\text {total }}$ & $\mathrm{MgO}$ & $\mathrm{CaO}$ & $\mathrm{Na}_{2} \mathrm{O}$ & $\mathrm{K}_{2} \mathrm{O}$ & $\mathrm{P}_{2} \mathrm{O}_{5}$ & $\mathrm{SO}_{3}$ & L.O.I. \\
\hline & 1.77 & 0.04 & 0.45 & 6.45 & 52.15 & 0.46 & 1.52 & 0.23 & 0.02 & 0.02 & 0.07 & 12.2 \\
\hline
\end{tabular}

\subsection{Blend Process}

The blend process of high-Mn iron ore with the Um Bogma manganese ore aims at upgrading the content of manganese in the final mixture to be a suitable raw material for ferromanganese alloys. Manganese alloys are required for steelmaking due to the role of manganese in sulfur-fixing that prevents the formation of a liquid iron sulfide at the grain boundaries, in addition to other aspects such as deoxidizing
[18]. To attain the suitable blend ratio for the production of high carbon ferromanganese alloys, the contents of $\mathrm{Fe}$ and $\mathrm{Mn}, \mathrm{Mn} / \mathrm{Fe}$ ratio, slag components $\left(\mathrm{Al}_{2} \mathrm{O}_{3}+\mathrm{SiO}_{2}\right)$ and the concentrations of sulfur $\left(\mathrm{SO}_{3}\right)$ and phosphorous $\left(\mathrm{P}_{2} \mathrm{O}_{5}\right)$ must be taken into account [19-21].

As illustrated in Table 3, the manganese content of the mixture gradually increases with increasing the blend ratio, and vice versa for the content of iron. For instance, the assay of mixture at weight ratio of $1 / 2$ (El-Gedida sample/Um Bogma sample) reveals 46.64 wt.\% $\mathrm{Mn}$ and 17.61 wt.\% Fe 
with $\mathrm{Mn} /$ Fe ratio 2.64/1, whereas the weight ratio of $1 / 6$ (ElGedida sample/Um Bogma sample) leads to a mixture containing 55.68 wt.\% $\mathrm{Mn}$ and 9.13 wt.\% Fe with $\mathrm{Mn} / \mathrm{Fe}$ ratio 6.09/1. Considering slag components, the weight ratio $1 / 2$ (El-Gedida sample/Um Bogma sample) results in a mixture containing 0.46 wt. $\% \mathrm{Al}_{2} \mathrm{O}_{3}$ and 0.87 wt.\% $\mathrm{SiO}_{2}$, whereas the weight ratio of $1 / 6$ (El-Gedida sample/Um Bogma sample) produces a mixture containing 0. 79 wt.\% $\mathrm{Al}_{2} \mathrm{O}_{3}$ and 0.74 wt.\% $\mathrm{SiO}_{2}$. For phosphorous, the blended sample at weight ratio of $1 / 2$ (El-Gedida sample/Um Bogma sample) contains 0.09 wt. $\% \mathrm{P}_{2} \mathrm{O}_{5}$, while the blended one at the ratio 1/6 (El-Gedida sample/Um Bogma sample) contains 0.06 wt. $\% \mathrm{P}_{2} \mathrm{O}_{5}$.

The market survey on manganese ore issued by the Indian Bureau of Mines [19] includes standard specifications for the raw materials exploited for the high carbon ferromanganese alloys. According to these specifications, the maximum content of $\mathrm{Fe}$ must not exceed $15 \%$, while the minimum content of $\mathrm{Mn}$ must be $38 \%$. The proper $\mathrm{Mn} / \mathrm{Fe}$ ratio for the ferromanganese alloys starts at 6.0. Moreover, the sum of slag constitutes $\left(\mathrm{Al}_{2} \mathrm{O}_{3}+\mathrm{SiO}_{2}\right)$ must not increase more than $8 \%$ in the raw materials. Also, the maximum content of phosphorous in the blended ores is recommended to be $0.16 \% \mathrm{P}_{2} \mathrm{O}_{5}$, while the maximum concentration of sulfur is tolerant at $0.14 \% \mathrm{SO}_{3}$. As listed in Table 3, the weight ratio $1 / 6$ is considered to be a desirable ratio at which it can be obtained a proper mixture for the manufacture of high carbon ferromanganese alloys. Thus, the high-Mn iron ore of ElGedida mine can be of economic potential as blend material with the Um Bogma manganese ore.

Table 3. Chemical assays of the blend ratios.

\begin{tabular}{llllll}
\hline \multirow{2}{*}{$\begin{array}{l}\text { Major oxides } \\
(\mathbf{1 0 0} \%)\end{array}$} & \multicolumn{5}{c}{ Blend ratios (El-Gedida sample/ Um Bogma sample) } \\
\cline { 2 - 6 } & $\mathbf{1 / 2}$ & $\mathbf{1 / 3}$ & $\mathbf{1 / 4}$ & $\mathbf{1 / 5}$ & $\mathbf{1 / 6}$ \\
\hline $\mathrm{SiO}_{2}$ & 0.87 & 0.85 & 0.80 & 0.79 & 0.74 \\
$\mathrm{Al}_{2} \mathrm{O}_{3}$ & 0.46 & 0.51 & 0.62 & 0.71 & 0.79 \\
$\mathrm{MnO}$ & 63.51 & 69.42 & 74.12 & 76.64 & 78.24 \\
$\mathrm{Fe}_{2} \mathrm{O}_{3}$ & 25.17 & 20.20 & 16.18 & 14.85 & 13.05 \\
$\mathrm{MgO}$ & 0.21 & 0.26 & 0.29 & 0.34 & 0.38 \\
$\mathrm{CaO}$ & 1.94 & 1.54 & 1.39 & 1.22 & 0.96 \\
$\mathrm{Na}_{2} \mathrm{O}$ & 1.35 & 0.99 & 0.86 & 0.76 & 0.62 \\
$\mathrm{~K}_{2} \mathrm{O}$ & 0.75 & 0.79 & 0.85 & 0.88 & 0.94 \\
$\mathrm{P}_{2} \mathrm{O}$ & 0.09 & 0.08 & 0.07 & 0.06 & 0.06 \\
$\mathrm{SO}_{3}$ & 0.25 & 0.19 & 0.16 & 0.14 & 0.11 \\
$\mathrm{Cl}$ & 0.98 & 0.85 & 0.71 & 0.59 & 0.37 \\
L.O.I & 4.41 & 4.30 & 3.92 & 3.01 & 3.77 \\
\hline
\end{tabular}

\section{Conclusion}

i. Microscopic investigations of the high-Mn iron ore revealed the complexity of interlocking between iron and manganese minerals, resulting in difficult liberation during the size reduction process.

ii. Magnetic separation of the high-Mn iron ore produced iron concentrate that contains $52.15 \mathrm{wt} . \% \mathrm{Fe}$ and undesirable Mn content (6.45 wt.\%) for steelmaking at the Egyptian Iron $\&$ Steel Company, Cairo. Hence, the magnetic separation is unsuitable for exploiting the high-Mn iron of El-Gedida iron mine.

iii. Results of magnetic separation support the prediction of microscopic studies regarding the difficult liberation of iron minerals from manganese phases.

iv. Blending the high-Mn iron ore with Um Bogma manganese ore at weight ratio of 1/6 (El-Gedida sample/Um Bogma sample) resulted in a mixture containing $55.68 \mathrm{wt} . \%$ $\mathrm{Mn}$ and 9.13 wt.\% Fe with $\mathrm{Mn} / \mathrm{Fe}$ ratio $6.09 / 1$. The chemical characterization of this mixture at weight ratio of $1 / 6$ is consistent with the standard specifications issued by the Indian Bureau of Mines (2014) for the production of ferromanganese alloys. Thus, the blend process is considered the effective method for exploiting the high-Mn iron ore of El-Gedida mine.

\section{Acknowledgement}

Authors expand their sincere thanks to Dr. M. Mansour, the Chairman of El-Bahariya Oasis Sector, Egyptian Iron \& Steel Company, for his collaboration during the field excursions in El-Gedida iron mine.

\section{References}

[1] Salama W, El Aref M, Gaupp R. Mineralogical and geochemical investigations of the Middle Eocene ironstones, El Bahariya Depression, Western Desert, Egypt. Gondwana Research 2012; 22: 717-736.

[2] Faraghaly M G. Beneficiation of El-Gedida Barite Iron Ore. Journal of Engineering Science 2002; 30: 779-812.

[3] Linchevsky B, Soboleevsky A, Kalenen A. Iron and Steel making. Mir publishers, Moscow 1983, pp. 11-19.

[4] El Bassyony A A. Geological Setting and Origin of El Harra Iron Ores, Bahariya Oases, Western Desert, Egypt. Annal of Geological Survey of Egypt 2000; 23: 213-222.

[5] Baioumy H M, Khedr M Z, Ahmed A H. Mineralogy, geochemistry and origin of $\mathrm{Mn}$ in the high-Mn iron ores, Bahariya Oasis, Egypt. Ore Geology Reviews 2012, 1-12.

[6] Pihura D, Oruc M, Lamut J. Selective oxidation of manganese in molten pig iron. Materials and technology 2010; 44 (5): 235-238.

[7] Terayama K, Ishiguro T, Watanabe H. Reduction Mechanism of Iron-Manganese Oxide with Carbon. Materials Transactions 1996; 37: 1247-1250.

[8] Atui L, Ryzhonkov D I, Sorin S B, Drozdov N N. Theory of Metallurgical Processes: Joint reduction of oxide mixtures containing $\mathrm{Fe}_{2} \mathrm{O}_{3}, \mathrm{MnO}_{2}$, and $\mathrm{NiO}$ with soild carbon. Steel in Translation 1999: 29: 47-49.

[9] El Geassy A, Nasr M I, Yousef M A, Khedr M H, Bahgat M. Behavior of manganese oxides during magnetising reduction of Baharia iron ore by $\mathrm{CO}-\mathrm{CO}_{2}$ gas mixture. Ironmaking and Steelmaking 2008; 27: 117-126.

[10] Saad N A, Zidan B I, Khalil K I. Geochemistry and origin of the manganese deposits in the Umm Bogma region, west central Sinai, Egypt. Journal of African Earth Sciences 1994; 19: 109-116. 
[11] Abouzeid A M, Khalid A M. Mineral Industry in Egypty-Part I: Metallic Mineral Commodities. Natural Resources 2011; 2: 35-53.

[12] Khalifa I H, Seif R A. Geochemistry of manganese-iron ores at Um Bogma area, west central Sinai, Egypt. International Journal of Advanced Scientific and Technical Research 2014; 6: $258-283$.

[13] Young Y U, Chaoying Q I. Magnetizing Roasting Mechanism and Effective Ore Dressing Process for Oolitic Hematite Ore. Journal of Wuhan University of Technology-Mater. Sci. Ed. 2011; 26 (2): 176-181.

[14] Tomanec R, Milovanovic J..Mineral liberation and energy saving strategies in mineral processing. Fizykochemiczne Problemy Mineralurgii 1994; 28: 195-205.

[15] Amstutz G C, Giger H. Stereological methods applied to mineralogy, petrology, mineral deposits and ceramics. Journal of Microscopy 1972; 95: 145-164.

[16] Petruk W. Applied Mineralogy in the Mining Industry. Elsevier Science B.V 2000, pp. 83-94.
[17] El-Faramawy H, Mattar T, Eissa M, El-Fawakhry K, Ahmed M A. Demanganisation of high manganese pig iron to produce high manganese slag. Maney for the institute of Materials, Minerals and Mining 2004; 31 (1): 23-30.

[18] Gutzmer J, Beukes N J. Iron and manganese ore deposits: Mineralogy, geochemistry and Economic Geology. Encyclopedia of Life Support Systems, UNESCO 2002; 532-545.

[19] Market Survey on Manganese Ore. Indian Bureau of Mines, Ministry of Mines, Nagpur 2014, pp. 11-20.

[20] Vorobyov V, Golunov A, Ignatyev A. Production of manganese ferroalloys from rich high-bacsicity ores. CIS Iron and Steel Review 2010; 19-22.

[21] Eissa M, El-Faramawy H, Ahmed A, Nabil S. Parameters Affecting the Production of High Carbon Ferromanganese in Closed Submerged Arc Furnace. Journal of Minerals\& Materials Characterization\& Engineering 2012; 11 (1): 1-20. 